\title{
Performance of Seawater Activated Battery as Alternative Energy Resources
}

\begin{abstract}
Masrufaiyah $^{1}$, Ridho Hantoro ${ }^{1}$, Gunawan Nugroho ${ }^{1}$, Totok R. Biyanto ${ }^{1}$, Nur Laila Hamidah ${ }^{1}$
Abstract- Research on Freshwater and Seawater batteries, which using $\mathrm{Al}$ and $\mathrm{Cu}$ electrodes at variation of different electrolyte salinity, distance between electrodes and flowrate of electrolyte has been carried out. The galvanostatic discharge and Electrochemical Impedance Spectroscopy (EIS) of Al and $\mathrm{Cu}$ in seawater were investigated. The results showed the optimum condition with significant average potential discharge of $45,02 \mathrm{mV}$ and current of $0,440 \mathrm{~mA}$ obtained from combination of $5 \%$ electrolyte salinity, $2 \mathrm{~cm}$ space between electrodes and 0,5 liter/hour electrolyte rate. EIS studies revealed that the $\mathrm{Al}$ and $\mathrm{Cu}$ interficial electrochemical process in seawater was determined by an activation controlled reaction.
\end{abstract}

Keywords — Seawater Battery, Galvanostatic Discharge, Electrochemical Impedance Spectroscopy.

\section{INTRODUCTION}

$\mathrm{S}$ eawater batteries are important power sources for underwater instruments including military devices and commercial equipment [1]. Seawater Batteries which use seawater as the electrolyte are attractive power sources as they have moderate cost, excellent safety characteristics, infinite shelf life under dry conditions, and they are environmentally friendly. One of the key materials applied in such batteries was the metal anode which increases the cell voltage [2]. Magnesium was one of the important anode materials used in seawater activated battery because it can provide a high electrode potential of $-2.37 \mathrm{~V}$ vs normal hydrogen electrode (NHE), a high Faradic capacity and appropriate corrosion rate [3]. Previous investigations showed that $\mathrm{Mg}$ was applied as a sacrificial anode but it hardly found the requirements of seawater activated battery because it has bad electrochemical discharge properties [4]. Aluminum was developed to provide enough electrochemical activity to find the requirement of seawater activated battery. In this work, aluminum used as anode and copper as a cathode.

The self-discharge rate of aluminum is slower than magnesium. Moreover, aluminum has lower cost and larger capacity than magnesium. Copper has the second highest thermal conductivity properties after silver and a good electric conductivity, $6,0 \times 10^{7} \mathrm{ohm} / \mathrm{m}$ [5].

The voltage-time and current-time discharge curves of seawater battery were examined as a function of electrolyte salinity, space between electrodes and electrolyte rate. The effect of those condition to the galvanostatic discharge and electrochemical impedance spectroscopy (EIS) of Al and $\mathrm{Cu}$ in seawater were investigated. The study is extended to examine the performance characteristics of seawater battery.

\footnotetext{
${ }^{1}$ Masrufaiyah, Ridho Hantoro, Gunawan Nugroho, Totok R. Biyanto, and Nur Laila Hamidah are with Departement of Physics Engineering, ITS Surabaya, Indonesia. E-mail: masrufaiyah14@mhs.ep.its.ac.id; hantoro@ep.its.ac.id; gunawan@ep.its.ac.id; trb@ep.its.ac.id;
}

\section{METHOD}

The single cell of Seawater battery consisted of a form encasement including an anode, a cathode and electrolyte. The encasement was a rectangular trough of inside dimensions $4,7 \mathrm{~cm}, 2,9 \mathrm{~cm}$ and $7 \mathrm{~cm}$ height. The trough was provided of a vertical groove of rubber on its side walls to fix the electrodes at constant anodic-cathodic distance, $0,5 \mathrm{~cm}$ and $2 \mathrm{~cm}$ trough out all the measurement. In this cell, two holes of $0,5 \mathrm{~cm}$ diameter were drilled trough the walls of the trough, one at the bottom of one side and the other at the top of the opposite side. The electrolyte was forced to flow through these holes, in and out the cell. With a constant rate 0,5 litre/hour by means of a simple pump.

The qualitative and quantitative electrodes composition element composed electrodes was obtained from Energy Dispersive X-ray Spectroscopy (EDAX) and Inductively Coupled Plasma (ICP). The polarization and Electrochemical Impedance Spectroscopy (EIS) of experimental alloy anodes were measured. and the data were acquired and processed by the Nova software version 1.8 .

All the anode was cut from $0,15 \mathrm{~mm}$ thick sheet aluminum of dimensions $3 \mathrm{~cm} \times 2 \mathrm{~cm}$ which filled the entire cross section of the encasement. The cathodes were cut from $0,20 \mathrm{~mm}$ thick sheet of copper and had the same geometrical shape and dimension as the anodes. The employed electrolyte was synthetic seawater of 3\%, 4\% and $5 \%$ salinity. The salt water solution electrolyte was prepared by dissolving $3 \mathrm{~g}$ of $\mathrm{NaCl}$ in $100 \mathrm{ml}$ distilled water to get $3 \%$ water salinity. The discharge experiment of a cell was carried out through a 1-ohm resistor.

Voltage-time curves and current-time curves were measured under various conditions by digital multimeter. Two multimeters were needed in order to measure current and voltage across a resistor simultaneously. the Electrochemical Impedance Spectroscopy (EIS) was used to study the discharge behavior and corrosion mechanism of electrodes. 


\section{RESULT AND DISCUSSION}

The composition of electrodes was investigated by EDAX and ICP-OES (figure 1). Only the aluminum and copper was detected during the investigation of surface of the anode and cathode. The ICP-OES showed that the aluminum and copper composed in anode and cathode was high, 36847 ppm (anode) and 51702,3 ppm (cathode).

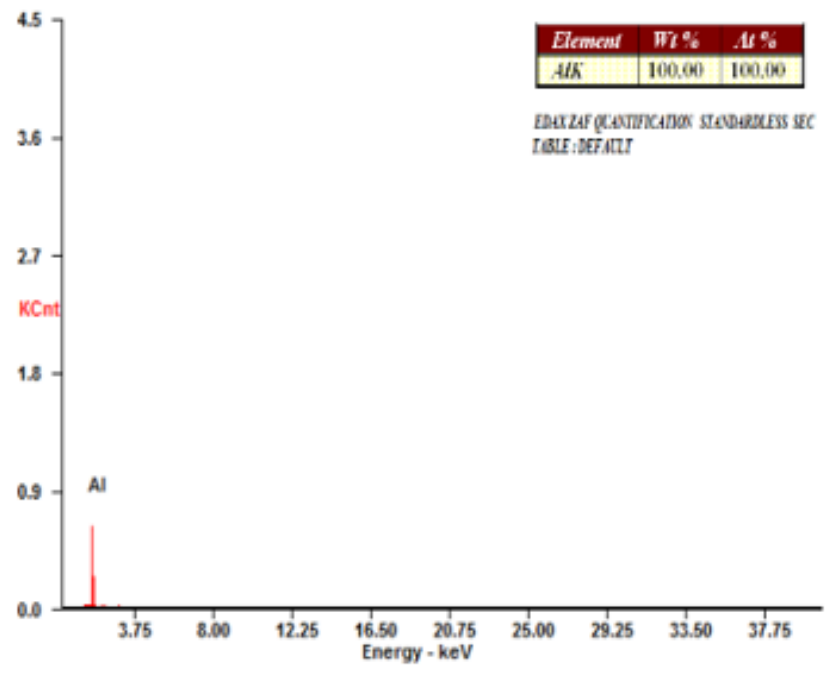

(a)

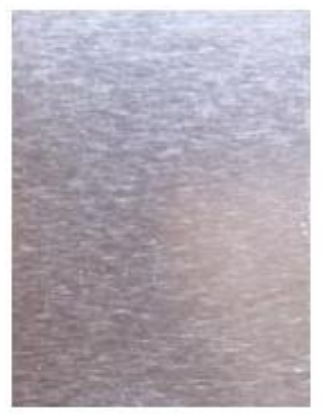

(a)

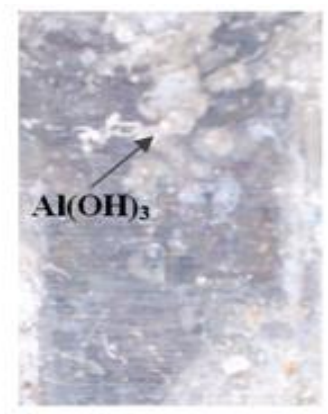

(b)

Figure 1. EDAX identification of (a) anode and (b) cathode.

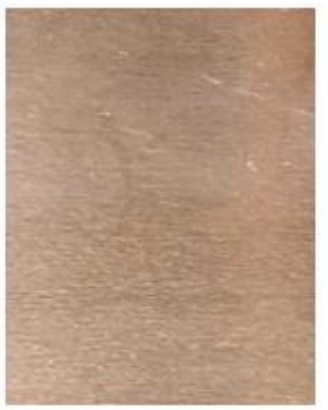

(c)
Copper was more electronegative than aluminum. Electrons would flow from internal and external circuit. in the external circuit, electrons flows from the aluminum $\rightarrow$ load $\rightarrow$ copper $\rightarrow$ dissolve oxygen (the opposite direction from the conventional current). But inside the solution, electron was carried by the ions flown from copper to aluminum in order to complete the circuit and replenish the electron lost by aluminum.

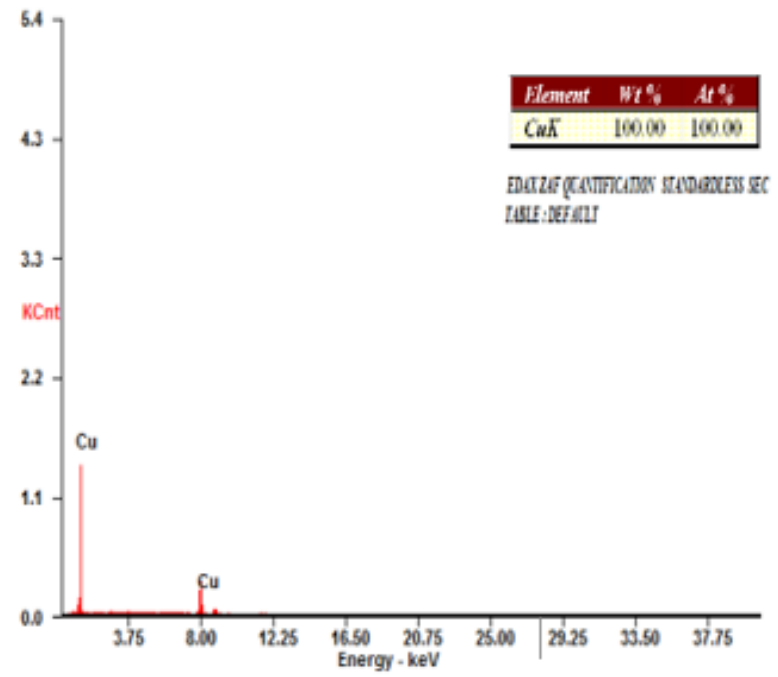

(b)

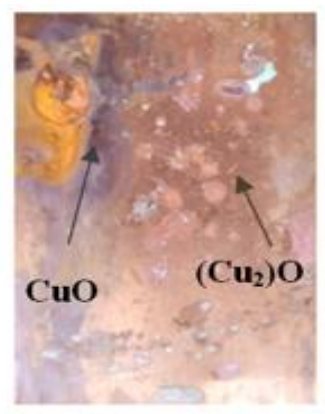

(d)

Figure 2. (a) aluminium before discharge, (b) aluminium after discharge, (c) copper before discharge and (d) copper after discharge.

Inside the cell, copper act as a source of electrons (the cathodes). Electrons passes external circuit through the resistor, then reduced the oxygen.

$$
\mathrm{O}_{2}+2 \mathrm{H}_{2} \mathrm{O}+4 \mathrm{e}^{-} \rightarrow 4 \mathrm{OH}^{-}
$$

(dissolved oxygen in the water)

This forms hydroxide $\left(\mathrm{OH}^{-}\right)$in the area near the electrode. The cell current decreases over long periods of time because the metals become coated with oxides. At the anode, the aluminum was oxidized:

$\mathrm{Al}+3 \mathrm{OH}^{-} \rightarrow \mathrm{Al}(\mathrm{OH})_{3(\mathrm{~s})}+3 \mathrm{e}^{-}$

This reaction would consume the aluminum and hydroxide to produce aluminum hydroxide, $\mathrm{Al}(\mathrm{OH})_{3(\mathrm{ss} \text {. Ions }}$ from the electrolyte will be flowed to the cathode and anode. The sodium ions $\left(\mathrm{Na}^{+}\right)$flowed to the cathode to neutralize the $\mathrm{OH}^{-}$ions produced at the copper electrode. The chlorine $\left(\mathrm{Cl}^{-}\right)$ions moved to aluminum to replace the $\mathrm{OH}^{-}$used up in dissolve oxygen reaction. The net result was electrons moving from copper to aluminum. the cell reaction was given by the following equation stoichiometrically:

$$
\mathrm{Al}+\frac{3}{4} \mathrm{O}_{2}+\frac{3}{2} \mathrm{H}_{2} \mathrm{O} \rightarrow \mathrm{Al}(\mathrm{OH})_{3(\mathrm{~s})}
$$

Beside that, there was additional corrosion reaction on anode that consumes the aluminum but didn't produce the current:

$$
2 \mathrm{H}^{+}+2 \mathrm{e}^{-} \rightarrow \mathrm{H}_{2}
$$

The copper didn't participate in the cell reaction chemistry. Electron passed through copper, then allowing the reduction of oxygen. When the copper was left to sit in the air, it can easily oxidize and it will turn reddish because the formation of cuprous oxide $\left(\mathrm{Cu}_{2} \mathrm{O}\right)$. When the copper was arranged into the cell, the Oxidation of aluminum $\left(\mathrm{E}^{\mathrm{o}}\right.$ net $=3,12 \mathrm{~V}$ ) by oxygen was more energetically favorable than the oxidation of copper metal to $\mathrm{Cu}_{2} \mathrm{O}\left(\mathrm{E}^{\mathrm{o}}{ }_{\text {net }}=1,18 \mathrm{~V}\right)$ or to $\mathrm{Cu}^{2+}\left(\mathrm{E}_{\text {net }}^{\mathrm{o}}=0,48 \mathrm{~V}\right)$. So, it's aluminum that was oxided 
instead. Some of copper also be oxidized resulting red $\mathrm{Cu}_{2} \mathrm{O}$ and black $\mathrm{CuO}$ deposit on the copper surface.

\section{A. Galvanostatic discharge behaviour}

The discharge performance of aluminum anode and copper cathode could be observed from its potential time curve. The potential of aluminum anode during discharge process was important because the potential difference between the anode and cathode was the driving force for the anode material to deliver electrons. The potentiodynamic polarization behavior of the aluminum and copper in the 3\%wt $\mathrm{NaCl}$ solution was shown in Figure 3. The polarization parameters measured from the polarization curves are given in Table 1.

TABLE 1.

CORROSION PARAMETERS OF ALUMINIUM AND COPPER UNDER 3 WT\% NACL SOLUTION OBTAINED FROM THE CORRESPONDING POLARIZATION CURVE

\begin{tabular}{cccc}
\hline \hline Electrodes & $\begin{array}{c}\text { Corrosion current } \\
\text { density } \mathbf{J}_{\text {corr }}\end{array}$ & $\begin{array}{c}\text { Corrosion potential } \\
\mathbf{E}_{\text {corr }}(\mathbf{v s} \text { Ag/AgCl) }\end{array}$ & $\begin{array}{c}\text { Polarization } \\
\text { resistance }\end{array}$ \\
\hline Aluminum & $29,0090 \mathrm{nA} \cdot \mathrm{cm}^{-2}$ & $-660,130 \mathrm{mV}$ & $23,4620 \mathrm{k} \Omega$ \\
Copper & $1,85450 \mu \mathrm{A} \cdot \mathrm{cm}^{-2}$ & $-207,990 \mathrm{mV}$ & $7,4700 \mathrm{k} \Omega$ \\
\hline \hline
\end{tabular}

Potentiodynamic polarization was an effective method for investigating the discharge behavior of aluminum anode over a wide anodic polarization. In addition, the anodic and cathodic branches of these polarization curves were not symetrical. The anodic branch, associated with the oxidation of the aluminum anode, showed its discharge activity during anodic polarization. The cathodic branch, probably related to the reduction of the hydrated protons, has well-developed tafel region. The corrosion current densities were evaluated from these polarization curves using tafel extrapolation of the cathodicbrances back to the corrosion potential.

Although the standard potential of the aluminum and copper are $-1,10$ volt and $-0,30$ to $-0,57$ volt (vs $\mathrm{Ag} / \mathrm{AgCl}$ ) but the steady-state working potential of aluminum and copper are generally about $-0,68$ volt and $-0,2$ volt (vs
$\mathrm{Ag} / \mathrm{AgCl}$ ) from Figure 3. This deviation in potential was caused the formation of aluminum hydroxide which improves the corrosion resistance of aluminum on the metal surface. Anodes which have more negative corrosion potential with higher corrosion current was beneficial to utilization of anode in the seawater battery.

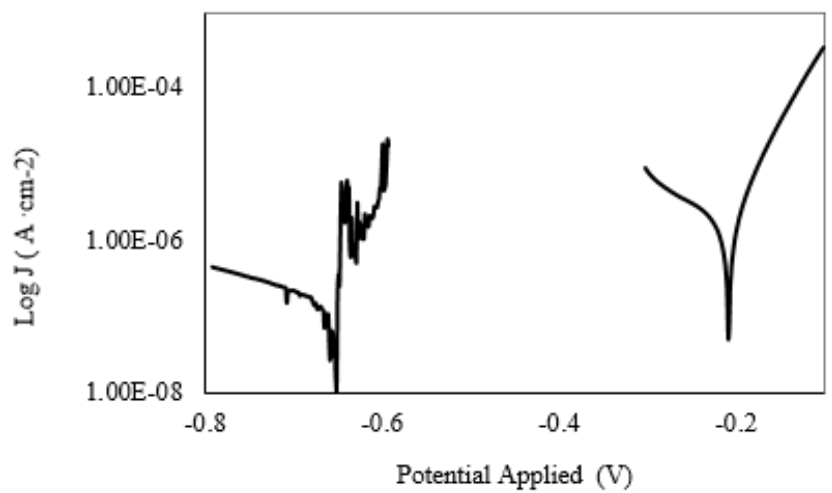

Figure 3. Poentiodynamic polarization behavior of aluminium and copper under $3 \%$ wt $\mathrm{NaCl}$ solution.

The voltage dependence on the space between electrodes and electrolyte salinity of cell was investigated for the cell with 0 liter/hour electrolyte rate, Figure 5. Figure 5 illustrated that voltage for aluminum copper pair is limited by the resistance of the electrolyte, i.e., space between electrode and salinity. As seen from figure 5, for the cell with $0,5 \mathrm{~cm}$ have higher voltage than $2 \mathrm{~cm}$ space between electrodes. it was caused the resistance of $2 \mathrm{~cm}$ space between electrodes higher than $0,5 \mathrm{~cm}$ space between electrodes. With the increased space between electrodes, the resistance increase to. On the other hand, from figure 6, the cell with $2 \mathrm{~cm}$ space between electrodes have higher voltages than 0,5 . The cathode reaction is restricted by the low solubility of oxygen in electrolyte. Dissolved oxygen seawater battery can provide cell voltage of about $1 \mathrm{~V}$. The bigger space of area between electrode can provide much more oxygen which is carried by flowing electrolyte.

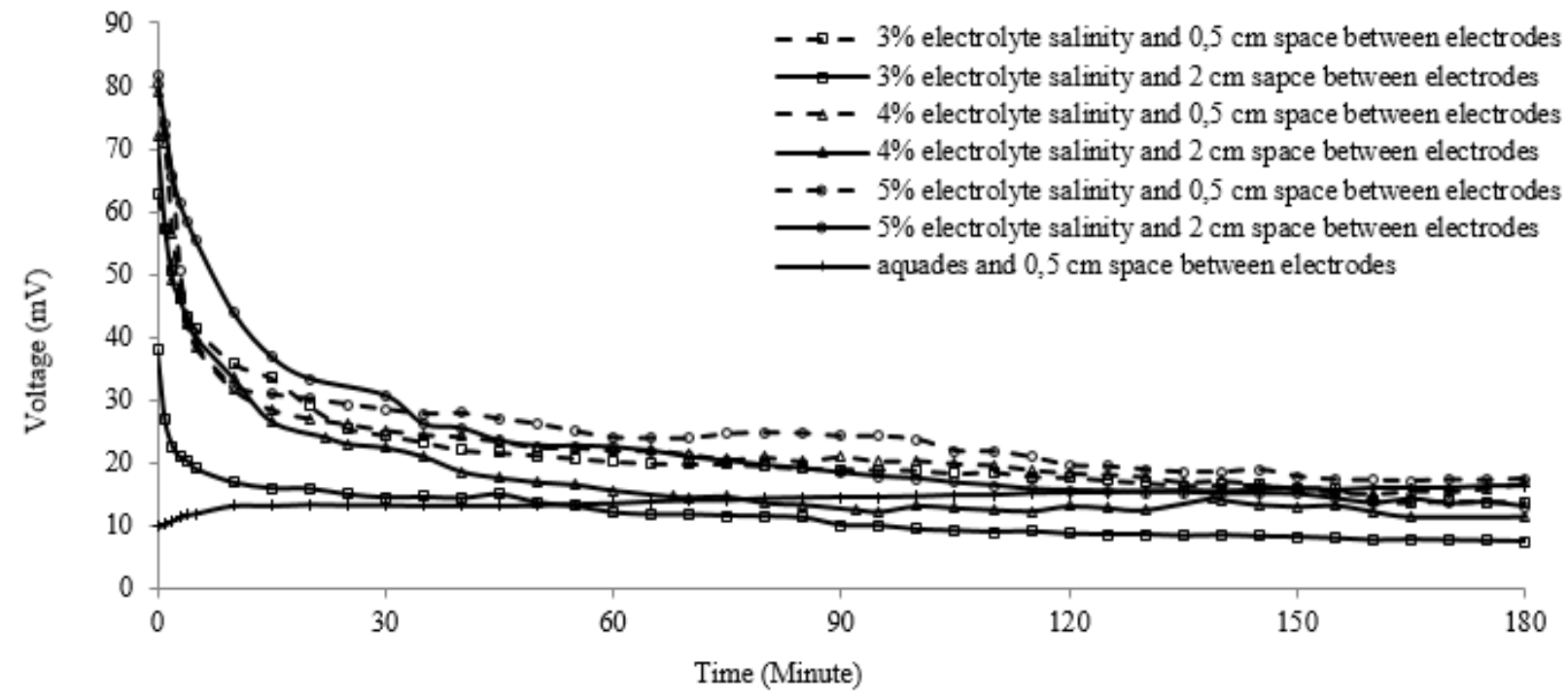

Figure 5. Galvanostatic discharge behavior of the cell under different conditions with electrolyte rate 0 litre/hour 


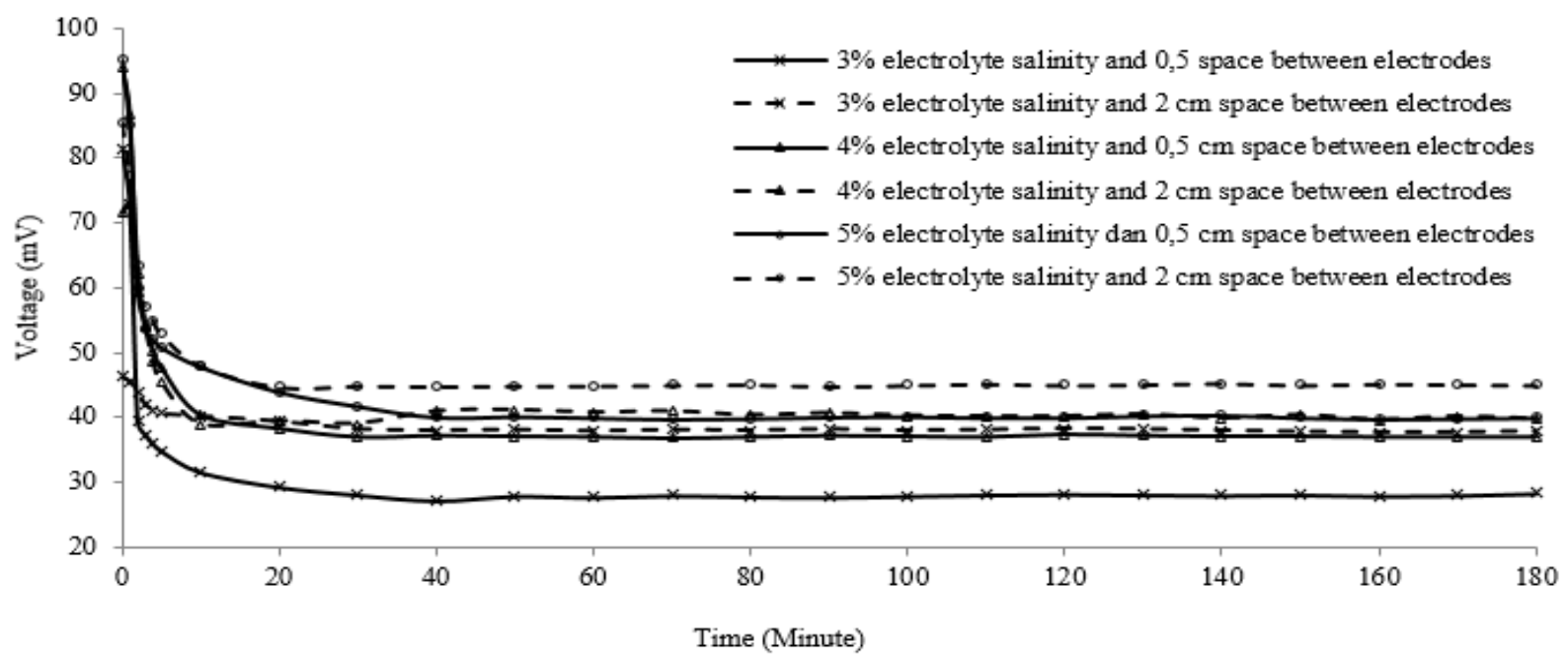

Figure 6. Galvanostatic discharge behavior of the cell under different conditions with electrolyte rate 0,5 litre/hour

Generally, in the few initial minute, it could be observed that the discharge voltage is relatively high and the voltages drop over time. This phenomenon is mainly considered to the $\mathrm{Al}(\mathrm{OH})_{3}$ film formed on the surface of aluminum, thus decreasing the reaction surface area and steady value and the rest of the discharge curve is almost flat. The electrolyte flow can sweep hydroxides on the electrode surfaces and can help revive the cell by bringing fresh oxygen into the area between anode and cathode. As the result, high and steady voltage obtained from the cell.

The same discharge behavior is obtained from Figure 5 and Figure 6, the cell with $5 \mathrm{wt} \%$ electrolyte salinity have the highest voltage. Table 2 was the average voltage discharge cell after minutes to 10 from Figure 5 and after minutes to 30 from Figure 6. From Figure 5 in the first thirty minute, the voltage was relatively low which aquades was the electrolyte solution. It shows the importance of $\mathrm{NaCl}$ in the electrolyte.

The voltages didn't depend strongly on the concentration of salt, despite the increased conductivity for stronger solution [6].

TABLE 2 .

THE AVERAge Voltage OBTAINED FROM FIGURE 5 AND FiguRe 6

\begin{tabular}{ccccc}
\hline \hline $\begin{array}{c}\text { Electrolyte } \\
\text { rate } \\
\text { (litre/hour) }\end{array}$ & $\begin{array}{c}\text { Space } \\
\text { between } \\
\text { electrodes } \\
(\mathbf{c m})\end{array}$ & $\begin{array}{c}\text { Electrolyte } \\
\text { salinity(\%) }\end{array}$ & $\begin{array}{c}\text { Average } \\
\text { voltage } \\
(\mathbf{m V})\end{array}$ & $\begin{array}{c}\text { Averagecurrent } \\
(\boldsymbol{\mu A})\end{array}$ \\
\hline $\mathbf{0}$ & 0,5 & 3 & 19,67 & 192,69 \\
& & 4 & 20,53 & 201,32 \\
& 2 & 3 & 22,94 & 215,43 \\
\cline { 2 - 5 } & & 4 & 10,90 & 101,03 \\
& 0,5 & 3 & 15,85 & 153,31 \\
& & 4 & 27,94 & 273,68 \\
& & 5 & 40,16 & 365,44 \\
& 2 & 3 & 38,01 & 371,87 \\
& & 4 & 40,24 & 393,69 \\
& & 5 & 45,02 & 440,19 \\
\hline Aquades & 0,5 & & 14,51 & 142,09 \\
\hline \hline
\end{tabular}

Conductivity was increased by the amount of salt in the electrolyte, but the rate of the electrochemical reaction was limited by the amount of oxygen in solution. The conductivity of the electrolyte should be high enough that the $I R$ polarization was not excessively large for practical operation. Table 3 shows the typical ranges of specific conductivities for lectrolyte which have range $3 \mathrm{wt} \%$ to 5 $\mathrm{wt} \%$. The electrolyte conductivity and cell resistance be correlated with the following formula:

$$
R=\frac{1}{\sigma} \frac{l}{A}
$$

Where $\mathrm{R}$ was cell resistance $(\mathrm{ohm}), \sigma$ was electrolyte conductivity (siemen), 1 was space between electrodes and A was size area of electrode $\left(\mathrm{m}^{2}\right)$. The cell resistance was inversely related to electrolyte conductivity.

TABLE 3.

CONDUCTIVITY OF NACL SOLUTION

\begin{tabular}{ccc}
\hline \hline $\begin{array}{c}\text { Salinity of NaCl } \\
\text { solution (wt \%) }\end{array}$ & $\begin{array}{c}\text { Conductivity } \\
\text { (miliSiemen) }\end{array}$ & $\begin{array}{c}\text { Temperature of NaCl } \\
\text { solution }\left({ }^{(} \mathbf{C}\right)\end{array}$ \\
\hline 3 & 44,7 & 31 \\
4 & 59,3 & 31,3 \\
5 & 73,9 & 31,4 \\
\hline \hline
\end{tabular}

Although the available energy of a battery depends on the basic electrochemical reactions at both electrodes, there are many factors which affect the magnitude of the chargetransfer reaction, diffusion rates, and magnitude formulation and design, electrolyte conductivity, and nature of the separators, among others.

Figure 7 shows voltage-time curve modeled under $3 \mathrm{wt} \%$ electrolyte salinity, $0,5 \mathrm{~cm}$ between electrodes and 0 litre/hour electrolyte rate use originlab software. With $\log 3 \mathrm{P} 1$ model, modeled curve and discharge voltage curve reach high fitting which was show with 0,98519 adj.Rsquare value. The fitting results general equation $y=a-b$ $\ln (x+c)$ where $y$ was cell voltage and $x$ was time. The logarithmic equation resulted fitting on the Figure 7 was identic with voltage equation of cell connected to the load that given by Nernst equation.

$$
\mathrm{E}=\mathrm{E}^{0}-\frac{\mathrm{RT}}{\mathrm{nF}} \ln \frac{\mathrm{a}_{\mathrm{C}}^{\mathrm{c}} \mathrm{a}_{\mathrm{D}}^{\mathrm{d}}}{\mathrm{a}_{\mathrm{A}}^{\mathrm{a}} \mathrm{a}_{\mathrm{B}}^{\mathrm{b}}}
$$

Where $\mathrm{E}$ was cell voltage, $\mathrm{E}^{\mathrm{o}}$ was standard potential of the cell, $R$ was gas constant $(8,314 \mathrm{~J} / \mathrm{mol} \cdot \mathrm{K})$, $\mathrm{T}$ was absolute temperature $(\mathrm{K}), \mathrm{F}$ was faraday constant and a activity of relevant species. 


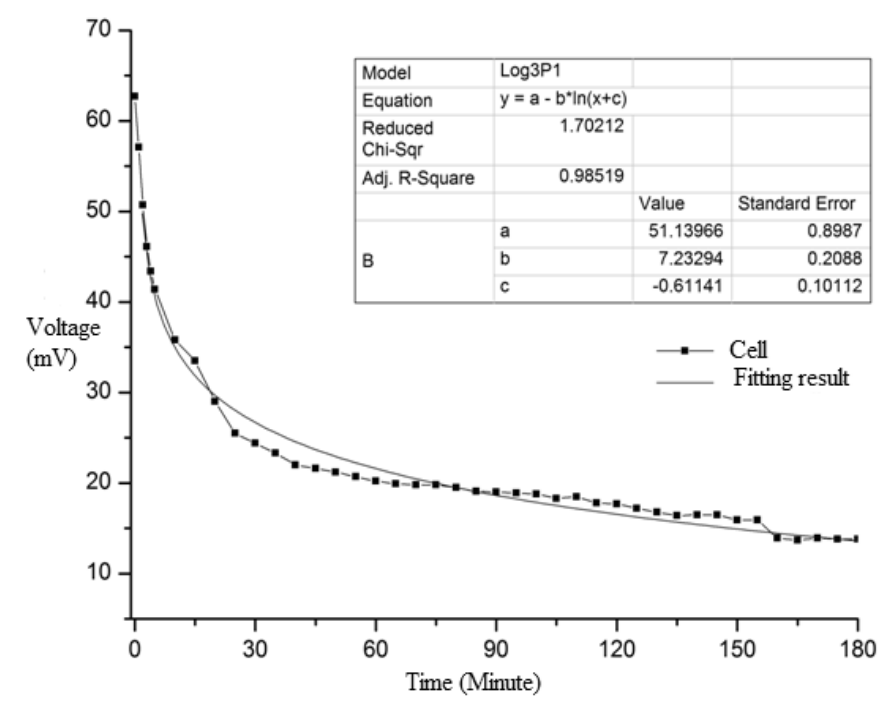

Figure 7. Voltage-time curve modeled cell under $3 \%$ electrolyte salinity, $0,5 \mathrm{~cm}$ space between electrodes and 0 litre/hour electrolyte rate

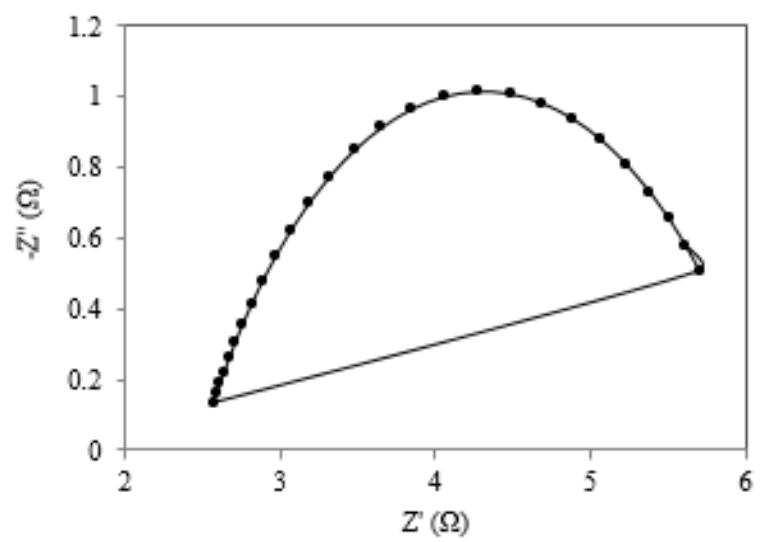

(a)

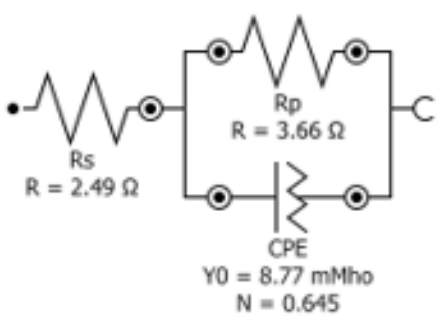

(c)

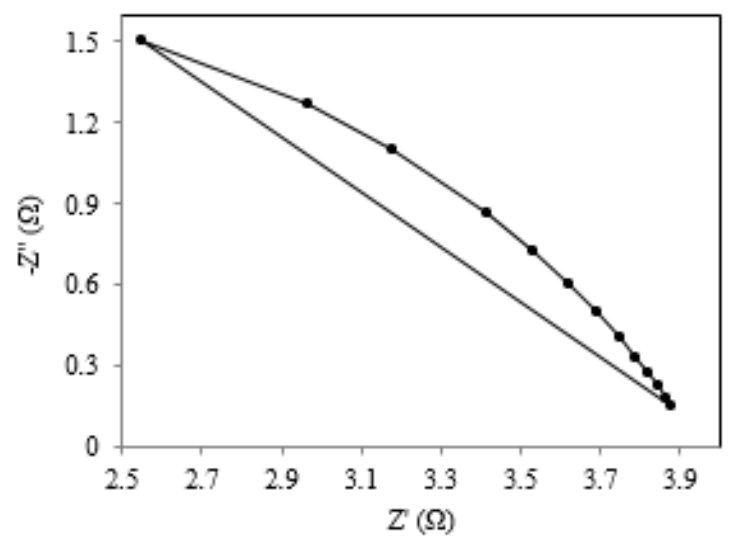

(b)

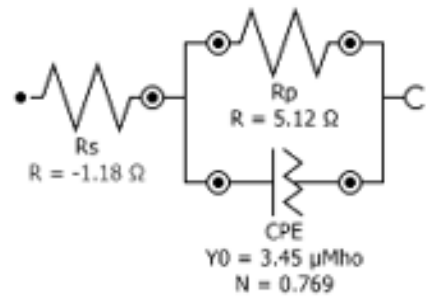

(d)

Figure 8. Electrochemical impedance spectroscopy measurements of electrodes (a) Nyquist plots for copper, (b) Nyquist plots for aluminium. The equivalent circuit of electrodes in $3 \% \mathrm{NaCl}$ solution (c) copper and (d) aluminium

The electrochemical impedance spectroscopy is used to study the discharge behavior and corrosion mechanism of aluminum and copper. The use of an AC signal can provide more information than that obtained from D.C. polarization technique. Generally, the simple electrochemical system consists of a solution resistance (Rs), a double-layer capacitance $(\mathrm{Cdl})$, and a charge-transfer resistance $(\mathrm{Rp})$. The impedance locus diagrams aluminum and copper are obtained by applying a frequency range of 0.01-100.000 $\mathrm{Hz}$ with $\mathrm{AC}$ amplitude of $0,02 \mathrm{~V}$. The $\mathrm{Z} /$ phase $(\theta)$ relation of the impedance was given by $Z^{\prime}=\mathrm{Z} \cos (\theta)$ for the real part and $Z^{\prime \prime}=\mathrm{Z} \sin (\theta)$ for the imaginary part. Typical Nyquist plots for the aluminum and copper was shown in Figure 8.
Respectively. The Nyquist plot shows that the curves of electrodes have a single capacitive loop at all frequencies. The nature of the curves indicates whether the system is activation controlled (a semicircle), diffusion-controlled (a $45^{\circ}$ straight line), or a combination of both. The diameter of the semicircle gives the charge-transfer resistance (Rp) at the electrode/electrolyte interface, which relates to the corrosion rate. The intercept on the $\mathrm{x}$-axis at the higher frequencies gives the solution resistance (Rs). In order to enable a detail analysis of the impedance diagram, the equivalent circuit model reported in Figure 8.

The obtained parameters such as Rs, Cdl and Rct are shown in Table 4. The Cdl normally includes two parameters i.e., $\mathrm{Y}$ and $\mathrm{n}$. The dimension of $\mathrm{Y}$ is $\Omega^{-1} \mathrm{~cm}^{-2} \mathrm{~s}^{\mathrm{n}}$ 
and $\mathrm{n}$ is an exponent without dimention. Parameter $\mathrm{Y}$ could be converted into the capacitance using the following equation.

$$
\mathrm{C}=\mathrm{Y}\left(\omega_{m}\right)^{n-1}
$$

Where $C$ was capacitance, $\omega_{m}$ was angular frequency at which the imaginary part of the impedance.

TABLE 4.

CORROSION PARAMETERS OBTAIN FROM EIS MEASUREMENT FOR ELECTRODES

\begin{tabular}{ccccc}
\hline \hline Electrode & $\boldsymbol{R}_{\boldsymbol{s}}(\boldsymbol{\Omega})$ & $\boldsymbol{R}_{\boldsymbol{p}}(\boldsymbol{\Omega})$ & Y0 & $\mathbf{n}$ \\
\hline $\mathrm{Cu}$ & 2,49 & 3,66 & $8,77 \mathrm{Mho}$ & 0,645 \\
$\mathrm{Al}$ & $-1,18$ & 5,12 & $3,45 \mu \mathrm{Mho}$ & 0,769 \\
\hline \hline
\end{tabular}

The corrosion rate is inversely related to Rp. Higher the $\mathrm{Rp}$ value, lower the corrosion rate. The low $\mathrm{Cdl}$ value for the aluminum implies the formation of relatively thick and compact protective film on the metal surface. In this research, semicircles have been obtained and this indicates that the electrode/electrolyte interface in this study is controlled predominantly by activation controlled processes.

\section{CONCLUSION}

The optimum condition is obtained from $0,5 \mathrm{~cm}$ electrodes distance and 5\% salinity and 0,5 liter/hour electrolyte rate with average potential discharge of 45,02 $\mathrm{mV}$ and current of $0,440 \mathrm{~mA}$. EIS studies reveal that the electrode/electrolyte interfacial process is determined by an activation controlled reaction.

\section{REFERENCES}

[1] W. S. D. Wilcock and P. C. Kauffman, "Development of a seawater battery for deep-water applications," J. Power Sources, vol. 66, no. 1-2, pp. 71-75, May 1997.

[2] M. Shinohara et al., "Deep-sea borehole seismological observatories in the western Pacific: temporal variation of seismic noise level and event detection," Ann. Geophys., vol. 49, no. 2-3, 2006.

[3] L. J. Liu and M. Schlesinger, "Corrosion of magnesium and its alloys," Corros. Sci., vol. 51, no. 8, pp. 1733-1737, 2009.

[4] P. K. Shen, A. C. C. Tseung, and C. Kuo, "Development of an aluminium/sea water battery for sub-sea applications," J. Power Sources, vol. 47, no. 1-2, pp. 119-127, Jan. 1994.

[5] G. M. Ehrlich, Linden's Handbook of Batteries. McGraw-Hill Education, 2002.

[6] S. V Chasteen, N. D. Chasteen, and P. Doherty, "The Salty Science of the Aluminium Air Battery,” Phys. Teach., vol. 46, pp. 544-547, 2008. 